\title{
THE CONCEPT OF «WAR» IN RUSSIAN LITERATURE OF THE XIX - EARLY XX CENTURY (M. Y. LERMONTOV, L. N. TOLSTOY, V. M. GARSHIN, L. N. ANDREEV)
}

\author{
Olga Evdokimova ${ }^{1}$, Irina Ivanova ${ }^{2 \star}$, Larisa Lyapaeva ${ }^{3}$, \\ Nataliia Obzhogina ${ }^{4}$, Lyudmila Sarbash ${ }^{5}$, Svetlana Fedyay ${ }^{6}$ \\ ${ }^{1}$ Chuvash State University, RUSSIA, evdokimova.ok@mail.ru \\ ${ }^{2}$ Chuvash State University, RUSSIA, leocon2@yandex.ru \\ ${ }^{3}$ Chuvash State University, RUSSIA, lar.lyapaeva@yandex.ru \\ ${ }^{4}$ Sen. Lect., Chuvash State University, RUSSIA, obnatur@gmail.com \\ ${ }^{5}$ Chuvash State University, RUSSIA, sarbash.lu@yandex.ru \\ ${ }^{6}$ Chuvash State University, RUSSIA, sfedyaj09@mail.ru \\ ${ }^{*}$ Corresponding Author
}

\begin{abstract}
The concept of "war" can be viewed as a landmark for understanding the picture of the world created by Russian writers during the XIX - early XX centuries. In the article, this concept is investigated in the dynamics of temporal and creative development based on the works of M.Y. Lermontov, L.N. Tolstoy, V.M. Garshin, in whose work the military theme occupies one of the main places, as well as L.N. Andreeva. The focus is on the poem by M.Y. Lermontov "Valerik", Caucasian and Sevastopol stories by L.N. Tolstoy, stories by V.M. Garshin, the story of L.N. Andreeva "Red Laughter". In the course of the analysis, the semantic components of the concept of "war" are highlighted, which are equally important for both the author and the reader. So, in particular, the concept of "war" is represented in the epic novel "War and Peace" in a wide semantic range: the patriotic thought about the war of liberation is combined with the understanding of its senseless cruelty and includes the philosophical and historical concept of the writer about the causes of the war, about "authorship" of a historical event. Based on the concept of concept, the authors of the article show that the chronotope of war is not limited to depicting historical events: it includes a content field associated with various moral and ethical aspects of the work. In the article, using the example of different types of literature (lyrics, epics) and genres (lyric poem, story, story, novel), as well as different periods of Russian literature, such meaningful antinomies as "life-death", "good-evil", dichotomy "man-nature" and the perception of insight - the spiritual and moral changes of man in war. Comprehension of various semantic facets of the concept of "war" in the work of M.Y. Lermontov, L.N. Tolstoy, V.M. Garshina, L.N. Andreeva gives grounds to show the commonality of views of these authors in understanding war as senseless cruelty both in the fate of a private person and in the fate of entire nations. As a result, the concept of "war" as a universal textual category allows one to see new semantic layers of a literary text in the works of Russian writers of the XIX - early XX centuries and to reveal new interpretations of it.
\end{abstract}

Keywords: Russian fiction of the XIX - early XX centuries, the concept of "war", the antinomy of "life-death".

\section{INTRODUCTION}

In the center of attention in the article is the concept of "war", the analysis of which makes it possible to reveal in the Russian literature of the XIX - early XX centuries a large content layer with characteristic motives, images, techniques and means of representation. The study of artistic concepts deepens the study of the peculiarities of the relationship between language, literature and culture, which makes it possible to 
show a kind of "multidimensionality" of the concept, as well as to trace its evolution in the context of both historical and artistic time.

In linguistics and literary studies, there are different definitions of the term "concept". So, for example, D.S. Likhachev believed that the concept is the result of a collision of the dictionary meaning of a word with a person's personal and national experience (Likhachev, 1997). This idea is confirmed by a number of specific linguistic studies (Romanova, Fedorova, 2017). Researcher N.V. Volodina focuses on the cultural significance of the content, the semiotic and mental nature of the concept (Volodina, 2010). The most general understanding of the concept as a "mental formation" that conditionally replaces an indefinite set of objects of the same kind was formulated by Y. V. Fomenko (Fomenko, 2004).

In literary criticism, the term concept means content that, through the prism of the author's vision, is realized in the semantic-associative context of a literary work (Evdokimova, Lyapaeva, Fedyai 2018; Evdokimova, Ivanova, Lyapaeva, Obzhogina, Sarbash, Fedyai, 2020; Sarbash, 2020; Zaitseva, 2011). In this regard, an important characteristic of a concept in literary criticism is its dialogic nature, that is, both the writer and the reader participate in its creation, whose task is to "complete" the content of the concept, fill it with new meaning. Since everyone has their own cultural experience, the concept always leaves room for conjecture, which allows you to reveal its semantic components. In our case, the concept makes it possible to show how the tradition of depicting war in all its content-richness and, above all, its philosophical and moral components, was formed in Russian literature of the XIX - early XX centuries.

The relevance of this article is determined by the fact that "war" invariably remains one of the constant themes of world culture, since "war" in its broad universal understanding again and again attracts attention. Each new generation reveals previously unknown facets of this problem, but one question remains unchanged - what are the causes of the war and what are its consequences, why there is a confrontation between "ours" - "aliens" and the "unconquered past" (Ivanova, Fedyay, Obzhogina, Evdokimova, Sarbash, Lyapaeva, 2020).

The purpose of the undertaken research is to show how in Russian literature writers of different generations depicted not only and not so much the wars themselves, but aspired to reveal universal human problems caused by the state of war, to understand why exactly war is becoming the only way to resolve conflicts, and most importantly - what are the consequences of war in the mind and soul of a person.

\section{METHODOLOGY}

Analysis of the scientific literature on the topic of the article made it possible to determine the methodological foundations and conceptual ideas of the study. The focus of the work is the concept of "war", which makes it possible to reveal one of the most complex and ambiguous problems in its interpretation in fiction - the problem of war and its consequences in human life. The contrastive-comparative method of research and the systematic approach were used at the stage of studying the theme of war in the works of Russian writers of the XIX - early XX centuries, due to which the most general patterns were revealed in understanding war as the greatest human tragedy, the consequences of which are virtually insurmountable. The principles of the synergetic approach, according to which complex open systems are regarded as self-organizing, are used to study the evolution of the concept of "war" in Russian literature of the XIX - early XX centuries. Using the observation method, results were obtained that can be presented in the form of materials for practical and seminars in the discipline "History of Russian Literature of the X - XX centuries", special courses on the history of Russian literature of the XIX century, student coursework and research work, as well as circles on Russian literature for both Russian-speaking students and foreign students.

The material and methodology of the study is due to the purpose of showing the peculiarities of the interpretation of the concept of "war" and the role of this concept in the formation of the traditions of Russian classical literature during the XIX - early XX centuries.

\section{RESULTS}

There is nothing more tragic in the history of mankind than war. That is why the phenomenon of war will always be the subject of broad public interest, scientific and philosophical understanding, simple human experience. Russian literature in the course of its development turned to the depiction of war from a variety of points of view: the tragedy of war with its eternal confrontation between life and death; peasant war and civil war; man in war, philosophical and moral aspects of this issue; Patriotic War and the patriotic theme in its national conditioning.

Our article is devoted to the concept of "war" in Russian literature of the XIX - early XX centuries. This 
period, admittedly, has long been a benchmark for many generations of writers, poets, playwrights. It was in the XIX century that traditions were laid in Russian classical literature that developed in the XX century and became actualized at the beginning of the XXI century. One of these traditions is the depiction of war as the greatest tragedy, where the confrontation between life and death takes the most extreme forms, revealing the true face of each participant in this tragedy.

The formation of this tradition during the XIX century can be traced to the example of the work of various writers, however, this topic was most clearly revealed in the works of M. Y. Lermontov (1814 - 1841), L.N. Tolstoy $(1828$ - 1910) and V.M. Garshin $(1855-1888)$. L. Tolstoy was born in the year when M. Lermontov wrote his first poem, and V. Garshin was born, when L. Tolstoy was already the author of the famous "Sevastopol stories". Precisely these writers, in fact, formed the Russian literary tradition of depicting war, which found continuation at the beginning of the XX century, in particular, in the stories of L.N. Andreev (1871 - 1919) «Red Laughter» (1904) and «Yoke of War» (1916).

Surprisingly, the origin of the tradition of depicting war in Russian literature is a poetic name - Mikhail Yurievich Lermontov.

The creativity of M. Y. Lermontov, unusually lyrical and confessional in nature, is characterized by many themes and motives, his lines and the leitmotif of loneliness are invariably recognizable in Russian poetry, and Lermontov's intonations are deeply original. At the same time, in the artistic world of M. Lermontov there is a theme that, it would seem, falls out of the general lyrical series, but which is surprisingly organic in the context of his poetic work and Russian literature in general - this is a military theme. As the researchers of M.Y. Lermontov, at the beginning of the XX century, the poet, before he was in the war, already spoke of this phenomenon as "going against religion, morality, and the harmonious life of nature" (Semyonov, 1914).

The theme of the war was not new for Russian poetry of the first third of the XIX century, which responded to the events of the Patriotic War of 1812. In this regard, it would be enough to name the poem by V.A. Zhukovsky "A Singer in the camp of Russian soldiers", the military elegies of K.N. Batyushkov, the hussar poetry of D. Davydov. Nevertheless, when we talk about the theme of war in Russian literature, we recall precisely M. Y. Lermontov, in whose work this topic was not only declared, but also developed from early works to poems of the last years of his life. Moreover, it was precisely in poetry and precisely in M. Y. Lermontov's poetry that for the first time in Russian literature the idea of the futility and tragedy of war, of its inhumanity and cruelty, sounded poetically and shrilly. In Lermontov's work, in fact, a conceptual idea of war was formed, which includes, first of all, a semantic component, with its eternal tragedy of life and death, as well as an attitude to war from the position of both a participant in events, and just a person.

The poet dedicated more than one work to the war: the poems "Field of Borodino" (1831), "Two Giants" (1832), "Borodino" (1837), "Testament" (1840), "Valerik" (1840), as well as the first, during the much imitative poem "Prisoner of the Caucasus" (1828) and one of the "Caucasian" poems - "Izmail-Bey" (1832). In addition, here you can also name the poems "Hadji-Abrek" (1833-1834) and "Mtsyri" (1839), where the author only slightly touched on the theme of war. So, "Mtsyri" begins with a mention of how "once a Russian general drove from the mountains to Tiflis ...", however, this mention indicates an event that became decisive in the fate of the protagonist ("he was taking a prisoner child ...").

In the works of M. Y. Lermontov two wars are depicted - the Patriotic War of 1812, which he knew about from the stories of his older contemporaries, and the Caucasian War, in which he participated directly. It was these two wars that became for the poet both the subject of thoughtful artistic analysis ("Izmail-Bey"), and the reason for reflection on a variety of topics: through familiarizing with the folk-poetic tradition ("Two Giants") to comprehend the national tragedy and the great war of 1812 ("Field of Borodino", "Borodino"), and then to a deeply personal experience of the cruelty and inhumanity of war in general ("Testament", "Valerik"). The poem "Valerik", completing this semantic series, is involuntarily perceived as a kind of artistic testament of M. Y. Lermontov, which arouses genuine interest, especially now, when the incessant military conflicts have become a reality of the time.

"Valerik" was written in 1840. This is a large verse, which some researchers call a poem (Savelyev, 2010, p. 277). Three years later, after the death of the poet, it was first published in the almanac "Morning Dawn". Compositionally, this work can be conditionally divided into 3 parts, where the first and third are an appeal to the beloved, and the second, the main one, is a detailed description of the camp life and military operations in the Caucasus, in which M. Y. Lermontov participated. The main event of the second part - the bloody battle on the Valerik River - is quite real. It happened on July 11, 1840 between the detachment of generallieutenant Galafeev (M. Y. Lermontov was as part of this detachment) and the Chechens. Valerik actually exists and flows into the Sunzha River, one of the Terek's tributaries. The name Valerik in translation into 
Russian means "the river of death" (Lermontov, 1988, p. 689). From 6 to 14 July 1840, Lermontov took part in battles and, according to his contemporaries, kept "The Journal of Military Operations" of the detachment of General Galafeev.

The fact that the events described are real, as real and the place where they took place, gives the whole poem a special tonality: the story of the lyrical hero about military operations sounds almost in epic intonations:

It was a terrible silence,

It did not last long,

But $<$ in $>$ this strange expectation

Not one heart beat. (Lermontov, 1988, p. 203)

The poet refers to the depiction of military operations, since he was a direct participant in the Caucasian war, its bloody and brutal battles, saw the death, death of his comrades in arms and at the same time showed miracles of courage. The private nature of the main theme of the poem was emphasized by the first and third compositional parts, where the lyrical hero rushes to his beloved with his thoughts and feelings. The role of the first line of the poem is also important here, which begins with Pushkin's intonations and which involuntarily refers to another love story: "I am writing to you...". However, of course, there is a significant difference: Lermontov, unlike Pushkin, is a letter from a man who went through the difficult roads of war and learned the value of life, and this is not only personal experience, but also a collective experience. Thus, the poet moves from the singular and particular to the universal and eternal problems - the tragedy of war, and with it the awareness of the fragility and transience of life in the face of death. The antinomy "life - death", deepening the content of the entire concept of "war", is stated by Lermontov in the framework of the personal experiences of the lyric hero, which in general gives the poem a special semantic capacity and intonational persuasiveness, forcing the reader to think about such eternal questions as, for example, why between life and death of a person is not love and happiness, but the tragedy of war.

The description of the war and its characteristic features is emphasized in the poem, which makes the image of the battle itself visible, almost tangible, but at the same time not exaggerated. So could write only a participant in the events who saw and survived everything himself: "in pairs the chain stands at a distance", "bayonets are burning under the sun of the south", "distant shot", "stray bullet", "the infantry stirred", "regimental music is buzzing", " guns clink, "a firefight ensued", the sky was ablaze with "breathing fire", "a fierce battle", "the detachment was showered with a hail of bullets from the tops of the trees", "terrible silence", "massacre began," wild wars ".

War in all its cruelty is presented in the poem in specific images and details of the battle, which allows the author to draw a deep, universal human conclusion about the causes and consequences of war, and most importantly, how miserable a person is in the face of life and death. So the thoughts of the lyrical hero go beyond the personal topic and acquire a universal human character:

I thought: "A pitiful person.

What does he want!.. The sky is clear,

There is a lot of place under the sky for everyone,

But incessantly and in vain

One is at enmity - why?" (Lermontov, 1988, p. 205)

The question raised in these lines of the poem is filled with deep semantic content, because it is addressed to himself, and to the participants in the battle, and to contemporaries and descendants.

The expanding semantic field of the concept makes it possible to build a synonymous series in which very different aspects of the problem are expressed - from glorious memories of past battles to the tragedy of today: "old times", "glorious sound", "daring collisions", "representations", "massacres", "river of death".

The author draws everyday pictures of war, but precisely in these everyday lives an idea of the true values in human life is formed. The images of individual participants in the events - the soldier, the captain, the "grayhaired barbel", the general, the lyrical hero, his kunak Galub, give a special acuteness to this idea. They are all very different in their functional role in the events described, but it was precisely the war that made them all equal in the face of death. So the antinomy "life - death" allows the author to push the boundaries of a lyrical story about one of the battles of the Caucasian War to universal human problems and reflections on 
how much a person's life can depend on the person himself.

L.N. Tolstoy also answers the question about the expediency of war - "why?", which sounded in the poem "Valerik", with his works about the war. The fact that M. Y. Lermontov was at the origins of L. Tolstoy's work has already been noted in Russian literary criticism in different years (Merezhkovsky, 1908; Semyonov, 1914; Lotman, 1997; Logunova, 2013). Lermontov and Tolstoy are very different: one is a lyric poet, the other is the author of the epic "War and Peace", nevertheless, they thought in the same way. It is no coincidence, that D. S. Merezhkovsky was convinced, that M. Lermontov's poem "Valerik" was "the first phenomenon in world literature of that special view of war, which L. Tolstoy so infinitely deepened" (Merezhkovsky, 1908, p. 31).

The depiction of war in the works of L. N. Tolstoy appears in a certain dynamics of development - from the war stories of the Caucasus and Sevastopol to the folk epic "War and Peace" (1863 - 1869). In the Caucasian stories ("Raid" 1853, "Cutting the forest" 1855, "Demoted" 1856, "Cossacks" 1863) L. N. Tolstoy does not yet write about the horrors of war, limiting himself to stating the fact - a ruined life, innocent blood shed. So, in the story "Raid" the writer shows a young warrant officer Alanin, mortally wounded in the first battle: his face, from which the "warlike delight" disappeared, was pale, a bloody stain stood out on his white shirt. The "Cossacks" describes Lukashka's deathbed torment from a Chechen bullet and, at the same time, Chechens hacked to death by the Cossacks. One of the handwritten versions of the story "Raid" gives a scene of a murder that Captain Khlopov could not prevent. The narrator asks the carabinieri who killed a mountain woman with a child in her arms: "... why did you do this?" (Tolstoy, 1935, vol. 3, p. 222). Asking the question about the perfect, he reminds the soldier of another woman with a child - Anisya and her son Alyoshka left at home, projecting the situation in the village on them. Would the carabiner have liked it if the factory brawlers in the inn had hit the soldier's girl and put a copper mug at his son's head? The semantic field of the concept "war", which absorbs all the incidents of war, is associated with the category of life-death as a moral dominant, with the moral responsibility of a person: before a dying carabinieri, a "bare-headed cub of a busurma" will certainly appear, pointing to him, who has violated the "sixth" Christian commandment.

The understanding of war and L. Tolstoy's attitude to it in "Sevastopol Stories" (1855 - 1856) deepens significantly: showing the feat of the Russian people, their self-sacrifice and heroism, the writer simultaneously conveys the horror and tragedy of what is happening, its inhumanity. War events appear as mass murder and unbearable human suffering. In "Sevastopol Stories" the author depicts "terrible, soulshaking spectacles": death and suffering, in the understanding of L. Tolstoy, are a conceptual constant of war. In the story "Sevastopol in December" L.N. Tolstoy shows the events in their true expression - "in blood, in suffering, in death." When describing the infirmary ("house of suffering"), the author makes us direct participants in what is happening: the repeated appeal "you will see" focuses attention on the presence of the reader. Throughout the course of the narrative, the writer conveys the everyday horror of war, notes the heavy smell of a "dead body" in the operating room. But, perhaps, the most important thing is the mortal suffering of a person: a sailor with a torn off leg, another defender of the city with a part of his chest torn out. The author writes that "you will see" how "a sharp crooked knife enters a white healthy body"; how "with a terrible, tearing cry and curses" the wounded comes to his senses; as a paramedic throws a severed hand (Tolstoy, 1935, vol. 4, p. 8).

In the story "Sevastopol in May" a dressing station makes a terrible impression: "pools of blood", unfortunate wounded who were soaking in each other's blood, doctors with gloomy faces who "stuck their fingers into the bullet wounds, feeling them, and turned over the broken off hanging limbs, despite the terrible groans and pleas of the sufferers" (Tolstoy, 1935, vol. 4, p. 37). The writer connects the sense of smell to the description of crippled people: there was an unbearable stinking smell - "heavy, thick, smelly". L.N. Tolstoy paints a terrible picture of pain and suffering: hundreds of wounded "with curses and prayers on their parched lips crawling, tossing and turning and groaning, - some between the corpses in a blossoming valley, others on stretchers, on bunks and on the bloody floor" (Tolstoy, 1935, vol. 4, p. 52).

The cruelty of war, its incompatibility with human nature is intensified by the antithesis of war-death - naturelife: in the morning "dewy flowering valley" there are "hundreds of fresh bloodied bodies of people with numb limbs"; during a truce, the boy collects a bouquet of blue flowers in the valley where the twisted, fetid bodies lie, and his attention is attracted by a terrible "headless" corpse. From the point of view of the writer's conceptual sphere, the contrast between the human and natural world is significant. The bloody horror of war is opposed by nature, beautiful in its splendor of life-giving forces, powerful vital energy of the coming day: fading stars fade, white fog stretches from the dark blue sea, cirrus clouds scatter across the azure sky, the sun rises - "a mighty beautiful light", promising the world and a person "love and happiness." Tolstoy's 
concept of "war" organically includes a spatial image of nature in the semantic area, symbolizing the abnormality of what is happening, highlighting the philosophical component of meaning. The nature-universe involuntarily makes a person think about the daily murder that is taking place. L.N. Tolstoy asks not at all rhetorical questions: why do Christian people who profess the "great law of love" do not realize what they are doing; why they violate the law of goodness embedded in the human soul; why people do not repent of what they have done. The truce ended, or, as the writer ironically remarked, the "white rags" were removed - and again human blood and death. L.N. Tolstoy considers "the truth", which is "beautiful" and which he loves "with all the strength of his soul," as the hero of "Sevastopol stories", trying to convey it to everyone.

"Sevastopol stories" paved the way for the epic novel "War and Peace", where the concept of "war" is represented in a wide semantic range: the patriotic thought about the war of liberation is combined with an understanding of its senseless cruelty and inhumanity and includes the philosophical and historical concept of the writer about the causes of war, about the "authorship" of the historical event.

Tolstoy's tradition in depicting a man in war, which comes from the "Sevastopol stories", is developed in the work of V. M. Garshin. The writer in the works "Four Days" (1877), "Coward" (1879), "From the Memoirs of Private Ivanov" (1883) refers to the topic that has already become traditional for Russian literature - a man in war, avoiding heroic pathos. V.M. Garshin, in the words of L.N. Tolstoy, does not depict the war "in a correct, beautiful and brilliant system", "with fluttering banners and prancing generals" (Tolstoy, 1935, vol. 4, p. 8). Suffering and death in the works of V. M. Garshin, as well as in L. Tolstoy's "Sevastopol stories", become a conceptual constant of war. Garshin depicts war in critical situations, thresholds for a person, as violence against human nature, as a test of death, a kind of "moral Golgotha" (Darensky, 2016, p. 276).

The concept of "war" in the story "Four days" by V. M. Garshin is plot-forming, manifests itself at all levels of the structure of the text and opens up new semantic layers of a work of art. Comprehension of various semantic facets of the concept allows revealing such meaningful concepts as "man", "nature", "evil" and "death"; the latter arise in the moral and ethical context of the narrative as the antinomy of "evil-good", "death-life". War appears as a terrible evil that deprives a person of the highest value of being - life.

In the semantic field of the concept of "war" in Garshin, one should single out such a constant as "man" - a man in his individual and personal manifestation, his "specialness" and various life relationships. And this unique, concrete person - Ivanov, who has a mother, beloved Masha, the war takes life. The hero believes that the newspapers will write about insignificant losses: a faceless arithmetic "one" has been killed, "an ordinary volunteer Ivanov" will not even be mentioned. Nor will the young soldier Sidorov, dying in battle and looking at Ivanov with big frightened eyes, be named. In the author's understanding of a person, one important point should be noted: the hero's idea of the murdered Turk changes, there is a realization of "him" as a person. Such faceless definitions of the shooting enemy as "he", "corpse", "theirs" are replaced by other designations - "neighbor", "my neighbor", "the person I killed", "unfortunate fellah", "my savior" (he flask with water). The hero, emotionally experiencing the battle, realizes that the killed man had such a sense of fear that was understandable to a person: Ivanov recalls how a Turk, not remembering himself, climbed on thorny branches of a bush, with a cry of "horror" clung to a dense hawthorn, as if seeking protection from nature. There is a maximum approach to oneself, an understanding of the "other" and an awareness of the common human grief for the murderer and the murdered. Garshin conveys an amazing synesthesia: Ivanov thinks about the suffering of his mother, who lost her son and cursed the whole world, and at the same time thinks about the old mother of the person he killed. In the mind of the wounded, a clear picture of a waiting Turkish mother arises: she sits at her wretched hut in the long evenings, looks to the far north and waits for her "beloved son", her worker and breadwinner (Garshin, 1984, p. 25).

In the writer's work, the concept of "war" organically interacts with the perception of insight - the spiritual and moral change of a person. The story "Four Days" is an image of the hero's unbearable physical and mental suffering, as a result of which there is a rethinking of life, the spiritual values of being. Seriously wounded Ivanov, not realizing what is with him - life or mortal agony, experiencing physical and mental torment, comes to the realization of a person's personal responsibility for what he has done, to the terrible understanding for himself that he is a murderer: "Before me lies the person I killed. Why did I kill him? ... What am I to blame, although I killed him? ... Murder, murderer" (Garshin, 1984, p. 27). The writer carries out the idea that, taking part in military events, a person is simultaneously both a victim of this evil and its creator: the killed is perceived by Ivanov precisely as "his victim".

Garshin shows that the very understanding of war in the mind of the hero changes and is substantially concretized. The hero, going to fight, did not want any harm, did not want to kill anyone. War was thought of as love for the motherland, valor and heroism. "Blinded by the idea", Ivanov saw his participation in the war in a heroic sacrificial halo: "... I will expose my chest to the bullets" (Garshin, 1984, p. 25). Now, on the 
battlefield, Ivanov considers himself a fool, he wants to understand the meaning of the events: "But have I done anything useful for military purposes, besides this murder?" (Garshin, 1984, p. 27). The image of the hero is revealed by the writer in the grip of painful questions and mortal anguish: why and for what he left his home, his dearest and closest people, went on a "thousand-kilometer campaign", suffering from heat and starving, and now he lies and dies painfully. V. M. Garshin's story "Four Days" is a terrible drama of "incomprehensible conscience and mind" of murder by people of each other (Uspensky, 1957, p. 149). War is defined as a terrible universal evil, as "suffering to people" invented by the world. A decaying corpse with worms swarming in it, a skeleton in a uniform with a "terrible bone smile" becomes a symbol of war.

The meaningful field of the concept "war" includes such a concept as death, which in the writer's depiction is the antinomy of life. However, death in the story of V. M. Garshin appears in another, very unusual reception: for the suffering hero, it is seen as an extraordinary blessing - the happiness of nothingness, the deliverance of a person from the intolerable torment of life. Ivanov "sees" his death in the guise of a decaying corpse, he appeals to her with a call to take him away. The person killed by him is perceived as "happy" because he does not feel anything - neither physical pain, nor moral torment, in the power of which the hero is.

The depiction of nature also contributes to highlighting the conceptual aspects of war in the work: in the transfer of the dichotomy of man and nature, V.M. Garshin continues the tradition of L.N. Tolstoy. In the image of Garshin, the spatial image of nature appears in the mind of the wounded in the antinomic categories of day-night, sun-moon. The day for the wounded Ivanov is an unbearable heat and thirst, a mercilessly scorching sun, a huge disk of which is "red as blood." The sun, which gives a person warmth and light, aggravates a person's physical suffering. The night is twilight and coolness, stars lighting up in the sky and the rising moon, which, as it seems to the wounded, looks at him with sympathy, "plaintively". The description of nature is aimed at the hero, the Garshin's landscape is psychological. In the story the perspective of perception of the natural world changes: at first it is literally a piece of earth and sky, seen with one eye of a prone person. Then Ivanov, who turned over on his back, opens up a huge heavenly space: he contemplates the huge sun and the twinkling stars. Nature expands to a cosmic scale, to the image of the Universe, in the boundless spaces of which both war and the person participating in it are lost.

Under the influence of V. Garshin's story "Four Days", at the height of the Russian-Japanese War, L. Andreev's story "Red Laughter" was written (the original title was "War"). "Red Laughter" was published in the collection "Knowledge" in 1904, but in the narrative there is not even a hint of the era and military reality. Contemporaries immediately attributed the work to the phenomena of not only Russian, but also world culture, noting the biblical subtext, humanistic pathos in combination with the new writing technique (Andreev, 1996, p. 620). The very process of creating the story took place on the verge of a nervous breakdown, his wife was forced to "be on duty" nearby: the writer was afraid to be alone - all this indicates that the author was experiencing what he portrayed as a personal tragedy (Andreev, 1996, p. 620).

The originality of the concept of "war" in the story is expressed not through the plot (it is outlined only in dotted lines), not through the depiction of battle scenes ending in victory or defeat, but through the consciousness of a person whose psyche is damaged by the war. It is this feature that becomes the main pictorial focus of the entire work. The story consists of 18 numbered passages and one more, "last" one, which is added without numbering - this is how the gradation of the final scenes is created, when everything comes down to the dominance of the Red Laughter.

Researchers attribute "Red Laughter" to works created in the style of expressionism, the poetics of which is characterized by increased expression, exaggerated images and tropes [Teryokhina, 2008, p. 39]. Such is the image of Red Laughter in the story: "...This is red laughter. When the earth goes crazy, it starts laughing like that. You know the earth has gone mad. There are no flowers or songs on it, it has become round, smooth, red, like a head from which the skin has been torn off..." (Andreev, 1996, p. 417).

The story mentions battles, long, lasting from 3 to 8 days, during which people die en masse (numbers from 4 to 5 thousand are named), and the consciousness of the hero who is inside these events, involuntarily, from fatigue, switches to the perspective of memories - this is how pictures of a peaceful, homely life emerge, where the main ones are the son's insomnia, the silence of the night, a samovar, tea with lemon, comfort. Memories contrast with reality, where everything is covered with blood, filled with screams, the noise of explosions and shots. It seems to the hero that the whole universe has gone mad. The sensations of the protagonist are in tune with the perception of the doctor, who sees and perceives the world eschatologically: everything around - the sky, the earth - is flooded with red, ghost people wander the steppe, becoming dangerous. Both the doctor and the hero see Red Laughter at the same time. However, in the center of the image are the fate of the heroes after their return to peaceful life. These are two brothers, one of whom returned from the war without both legs, goes mad and dies. The second brother, who takes 
care of him, listens to his stories about the war, watches how he runs a dry pen on paper from day to day, trying to create something like a will for posterity about the most important thing in life - "about flowers and songs", about "beauty and the world". But the sheet remains blank, and when my brother replaced the pen for a pencil in the hope that something of value will appear, then only curved lines remain on the paper. He could not create anything, and before the war, the hero did reviews of foreign literature, was an employee of the magazine. The second brother, after the death of the first, begins to see hallucinations, and gradually goes mad.

In L. Andreev's story, the semantic field of the concept of "war" arises from the totality of stories not only of the main characters, but also of other people, forming a single picture of understanding war as a massacre, as madness, as a place where "they make corpses from people". The story is full of stories of people who, after the war, could not return to their former peaceful life. In this regard, the fate of an officer who cannot withstand rest, silence, silence even at night is important, so relatives artificially create noise for him. But the culminating episode is the story of a mother who for a month received touching letters from her son, while her son was killed, which she read about in the newspaper list of messages. The mother commits suicide, thereby expressing her protest against the war: she does not need a world without her son.

The namelessness of the heroes of the story is fully justified, since it allows you to see through the madness of war the archetypes of eternal relationships of people: mother, son, child, brother. The piece ends with the dominance of Red Laughter. In our opinion, the image of Red Laughter becomes the embodiment of Satan's hellish machine. It is no accident that in the story the hero recalls "Paradise Returned" by D. Milton, who embodied this image in fiction. L. Andreev deliberately removes the entire concrete historical setting, including the names of the heroes, so that everything that happens is perceived in the context of any time, era, country, thus characterizing the whole world and all of humanity, which modern authors of works about the war also reflect on (Evdokimova, Ivanova, Lyapaeva, Obzhogina, Sarbash, Fedyai, 2020; Lyapaeva, 2017, p. 236).

\section{CONCLUSION}

An analysis of works about the war, created in Russian literature of the XIX - early XX centuries by writers of different eras and different creative aspirations, clearly convinces of how tragic and unnatural the state of war is for a person, regardless of the historical time in which he lives. These are such meaningful antinomies as "life-death", "good-evil", the dichotomy "man-nature" and the perception of insight - the spiritual and moral changes of a person in war. In this regard, the chronotope of war in the works of M. Y. Lermontov, L. N. Tolstoy, V. M. Garshin, L. N. Andreev is not limited to depicting historical events: it includes a content field associated with various moral and ethical aspects. As a result, summing up the results of the study, we can conclude that the concept of "war", which formed in Russian literature during the XIX - early XX centuries, is characterized by various semantic facets, the comprehension of which gives grounds to trace the main idea of works about war. War is a senseless cruelty both in the fate of a private person and in the fate of entire nations, and the preservation of national and universal values is the main problem that allows us to reveal the meaningful essence of the concept of "war" in all the multifaceted nature of its meanings. Depicting quite specific military events, Russian writers of the XIX - early XX centuries focus their attention, first of all, on a person, his thoughts and feelings caused by the war, and therefore each work from the distant past today sounds like a warning to all mankind about how destructive be the consequences of war, as well as a reminder of the value of life in all its manifestations.

\section{REFERENCE LIST}

Andreev, L.N. (1996). Diary of Satan: Novels. Stories and tales. Letters. Memoirs of Contemporaries. M. 640 p.

Darensky, V.Y. (2016). The test of death as the moral Golgotha of the hero in the prose of Vs. Garshin Problems of Historical Poetics. No. 14. P. 276-296.

Evdokimova, O. K., Lyapaeva, L. V., Fedyay, S. V. (2018). The concept of "house": creative roll call in the centuries (M. Lermontov, M. Tsvetaeva, G. Aigi). Bulletin of the Chuvash State Pedagogical University. AND I. Yakovleva. No. 2 (98). P. 78-84.

Evdokimova Olga, Ivanova Irina K., Lyapaeva Larisa, Obzhogina Nataliia, Sarbash Lyudmila, Fedyay Svetlana. (2020). The concept of "war" in Russian literature of the twentieth century/ Abstracts \& 
Proceedings of INTCESS 2020 - 7th International Conference on Education and Social Sciences, 2022 January 2020 - Dubai, UAE. P. 192-199.

Fomenko, Y.V. (2004). What Is Behind the Term "Concept"? Bulletin of Omsk University, No. 4. P. 113-116.

Garshin, V.M. (1984). Compositions. Stories. Essays. Articles. Letters. / Comp. V.I. Porudominsky. Moscow: Soviet Russia. 432 p.

Ivanova Irina K., Fedyay Svetlana V., Obzhogina Natalia Y., Evdokimova Olga K., Sarbash Lyudmila N., Lyapaeva Larisa V. (2020). Theme "insurmountable past" in Russian and foreign literature of the XX century/ Abstracts \& Proceedings of INTCESS 2020 - 7th International Conference on Education and Social Sciences, 20-22 January 2020 - Dubai, UAE. P. 228-231.

Lermontov, M. Y. (1988). Works: in 2 volumes. Vol. 1. / Comp. and comm. I.S. Chistova. M.: True. 720 p.

Likhachev, D.S. (1997). The concept of the Russian language Russian literature: Anthology. M.: Academia. P. 28-37.

Logunova, N.A. (2013). The specifics of military discourse in the works of M. Y. Lermontov. Philological sciences. Questions of theory and practice. No. 7 (25): in 2 hours. Part 1. P. 121-123.

Lotman, Y.M. (1997). The origins of the "Tolstoyan trend" in Russian literature of the 1830s // Lotman Y. M. About Russian literature. SPb: Art. P. 548-593.

Lyapaeva, L.V. (2017). The system of motives in Z. Prilepin's novel "Pathologies" // Nizhny Novgorod text of Russian literature: collection of articles. articles on the materials of the VI International. scientific. conf. 12-14 oct. 2017 - N. Novgorod: Minin University. P. 233-237.

Merezhkovsky, D.S. (1908). M.Y. Lermontov. The poet of superhumanity. 39 p. [Electronic resource] http://lermontov.rhga.ru/upload/iblock/61b/24_Merezhkovsky.pdf Date of treatment 12.12.2020

Romanova, T.N., Fedorova, N.A. (2017). Paremias with the "bread" component in the Russian, Ukrainian and Chuvash languages: a linguocultural aspect. National languages and literatures in multicultural conditions. Vol. 2. Cheboksary. P. 124-128.

Sarbash, L.N. (2020). The concept of "nature" in the drama of N.G. Garin-Mikhailovsky "Zora". Bulletin of the Mari State University. T.14. No. 3. P. 383-388.

Saveliev, A.E. (2010). The theme of the Caucasus and the Caucasian war in the works of M. Y. Lermontov. Problems of history, philology, culture. No. 2 (28). P. 270 - 283.

Semenov, L.P. (1914). Lermontov and Leo Tolstoy: on the centenary of the birth of Lermontov. Moscow: V.M. Sablina. 463 p. [Electronic resource] http://www.lermontov-lit.ru/lermontov/kritika/semenovlermontov-i-lev-tolstoj/vojna.htm Date of treatment 12.12.2020

Terekhina, V. (2008). Andreev Leonid Nikolaevich. Encyclopedic Dictionary of Expressionism. M.: IMLI RAN. P. 38-40.

Tolstoy, L.N. (1928-1958). Complete composition. In 90 tons / under total. ed. V.G. Chertkova. M.: Art. lit. References to this edition are in the text, indicating the volume and page.

Uspensky, G.I. (1957). The death of V.M. Garshin // Collected Works. In 9 volumes. V.9. / Ed. V.P. Druzin. M.: Art. liter. P. 139-151.

Volodina, N.V. (2010). Concepts, universals, stereotypes in the field of literary criticism: monograph. M.: Flinta: Science. 256 p.

Zaitseva, T.B. (2011). The concept of "love" in the works of A.P. Chekhov (for the anthology "Artistic constants of Russian literature"). Problems of history, philology, culture. No. 3 (33). P. 705-710. 